\title{
Nutrient limitation of cyanobacterial blooms: an enclosure experiment from the coastal zone of the NW Baltic proper
}

\author{
Emil Rydin*, Per Hyenstrand, Malin Gunnerhed, Peter Blomqvist \\ Uppsala University, Institute of Evolutionary Biology, Department of Limnology, Norbyv. 20, 752 36 Uppsala, Sweden
}

\begin{abstract}
In an enclosure experiment with nutrient additions performed in a western archipelago of the brackish Baltic Sea, cyanobacterial development was stimulated by phosphate additions. Large increases in particulate nitrogen, corresponding to $2.3 \mathrm{~g}$ nitrogen $\mathrm{m}^{-2}$ over the $25 \mathrm{~d}$ experiment, occurred in 2 enclosures receiving phosphorus but not nitrogen, which indicates a high capacity of nitrogen-fixing cyanobacteria to use molecular $\left(\mathrm{N}_{2}\right)$ rather than inorganic nitrogen as a source for growth in brackish waters. The amount of nitrogen fixed during the experimental period exceeded values reported from freshwater systems. At the end of the experiment, the phytoplankton community in enclosures receiving phosphate but not nitrate was dominated by filamentous nitrogen-fixing cyanobacteria. Enclosures receiving both phosphate and nitrate reached about the same concentration of phytoplankton biomass but had a lower abundance of nitrogen-fixing cyanobacteria than in bags to which phosphate but not nitrate was added. We hypothesize that the strong response of nitrogen-fixing cyanobacteria to additions of phosphate might be explained by the presence of a high concentration of bioavailable iron $\left(20 \mu \mathrm{g} \mathrm{l}^{-1}\right)$, as well as favorable weather conditions.
\end{abstract}

KEY WORDS: Nitrogen fixation $\cdot$ Phosphorus limitation $\cdot$ Iron $\cdot$ Baltic Sea

\section{INTRODUCTION}

Mass developments of nitrogen-fixing cyanobacteria such as Aphanizomenon spp. and Nodularia spumigena frequently occur in the Baltic Sea during summer (e.g. Niemi 1979, Willén \& Mattsson 1997, Stal et al. 1999). Recent findings suggest that cyanobacterial blooms in the Baltic Sea are a natural phenomenon that has occurred over long periods of time (Bianchi et al. 2000). However, there is a general consensus that increases in nutrient loading due to human activities has increased the magnitude and duration of the blooms. Phosphorus and nitrogen inputs during the past 5 decades have been estimated to have increased by factors of 8 and 4, respectively (Larsson et al. 1985), numbers that might be underestimations (Grimvall et

*E-mail: emil.rydin@ebc.uu.se al. 2000). An increased load of nutrients can be expected to stimulate primary production directly, but also through increased sedimentation of organic material that consumes dissolved oxygen by mineralization, eventually turning surface sediments anoxic (cf. Jonsson et al. 1990), also in shallow archipelago areas (Persson \& Jonsson 2000). Since iron is an important phosphorus-retaining element in coastal zone sediment (Carman \& Jonsson 1991, Jensen et al. 1995), an increasing prevalence of oxygen-depleted surface sediments would drastically decrease phosphorus and iron retention capacity (Mortimer 1941, 1942). These 2 elements are potential limiting factors to the development of cyanobacterial blooms in the Baltic (Balode et al. 1998, Hellström 1998, Howarth \& Marino 1998, Hyenstrand et al. 1999, Stal et al. 1999).

Phytoplankton nutrient limitation is a complex issue since (1) it can be overridden by light limitation, (2) nutrient requirements differ between phytoplank- 
ton species, and consequently there might be a difference between the species-specific and the community responses, and (3) a distinction must be made between yield limitation and the limitation of phytoplankton growth rate per se. Most studies, this one included, measure the accumulation of phytoplankton biomass or particulate matter over time rather than species or genera-specific production, which is often a parameter of great interest. This, however, is because the latter is almost impossible to measure when studied in situ.

Recently, Bianchi et al. (2000) argued that nitrogen generally limits the primary production in the Baltic proper, and that this has been the case for several centuries. Furthermore, Granéli et al. (1990) concluded that the availability of nitrogen limits the spring bloom of diatoms in the Baltic. However, during summer, bioavailable phosphorus in the euphotic zone, together with low levels of inorganic nitrogen, favor the development of nitrogen-fixing cyanobacterial species (Larsson et al. 2001). Nitrogen fixation in freshwater systems generally alleviates nitrogen shortage to the point of maintaining phosphorus limitation (Howarth et al. 1988, Hellström 1998). As a result, it is debated whether the nitrogen fixation rate is high enough to compensate for a shortage of inorganic nitrogen in the Baltic, leading to phosphorus limitation. This issue relates to whether the increased nitrogen removal by sewage treatment would be a costeffective measure for improving the water quality of the Baltic Sea.

The aim of the present study was to evaluate the effects of phosphate, nitrate and iron on cyanobacterial bloom formation during summer in a shallow, brackish, semi-enclosed bay, Lötafjärden. This bay is unaffected by local anthropogenic nutrient supply and is situated on the east coast of Sweden in the Alland Sea. The study involved enclosing epilimnetic water, adding nutrients every fourth day and evaluating the response of the phytoplankton community.

Table 1. Initial addition of nutrients $\left(\mu \mathrm{gl}^{-1}\right)$ to the bags (Day 0). Additions were repeated with half of the amounts every following fourth d. Total amount of added phosphorus during the experiment was 70, iron 700, and nitrogen $508 \mathrm{\mu g} \mathrm{l}^{-1}$

\begin{tabular}{|llccc|}
\hline $\begin{array}{l}\text { Bag (number } \\
\text { and label) }\end{array}$ & Addition & $\mathrm{PO}_{4}-\mathrm{P}$ & $\mathrm{NO}_{3}-\mathrm{N}$ & $\mathrm{FeCl}_{3}$-Fe \\
\hline 1. C (control) & $\mathrm{None}_{2}$ & 0 & 0 & 0 \\
2. $\mathrm{K}$ & $\mathrm{KH}_{2} \mathrm{PO}_{4}$ & 20 & 0 & 0 \\
3. $\mathrm{N}$ & $\mathrm{KNO}_{3}$ & 0 & 145 & 0 \\
4. NP & $\mathrm{KH}_{2} \mathrm{PO}_{4}+\mathrm{KNO}_{3}$ & 20 & 145 & 0 \\
5. FeP & $\mathrm{KH}_{2} \mathrm{PO}_{4}+\mathrm{FeCl}_{3}$ & 20 & 0 & 200 \\
6. FeN & $\mathrm{KNO}_{3}+\mathrm{FeCl}_{3}$ & 0 & 145 & 200 \\
7. FeNP & $\mathrm{KH}_{2} \mathrm{PO}_{4}+\mathrm{KNO}_{3}+\mathrm{FeCl}_{3}$ & 20 & 145 & 200 \\
\hline
\end{tabular}

\section{MATERIALS AND METHODS}

The enclosure experiment was performed in Lötafjärden $\left(60^{\circ} 13^{\prime} \mathrm{N}, 18^{\circ} 26^{\prime} \mathrm{E}\right)$, a $0.7 \mathrm{~km}^{2}$ semi-enclosed bay with an average depth of $2 \mathrm{~m}$. The salinity in the bay was $4 \%$, and the bedrock in the $2 \mathrm{~km}^{2}$ catchment area consists of granites and gneisses covered by glacial and post-glacial clay deposits. During the nutrient incubation experiment, between July 17 and August 11, 1999, the weather was sunny and the water temperature in the bay was ca. $21^{\circ} \mathrm{C}$.

Seven transparent, $2 \mathrm{~m}$ deep polyethylene bags were filled with $0.3 \mathrm{~m}^{3}$ of unfiltered epilimnion water and attached to a floating wooden frame with their openings fixed about $20 \mathrm{~cm}$ above the water's surface. To prevent contamination by bird droppings, transparent plexiglass lids were fastened $10 \mathrm{~cm}$ above the top of the bags, so that air was still allowed to flow through. Different combinations of phosphate, nitrate and iron were added to the bags every fourth days. One bag was left unfertilized, while the remaining 6 bags received (1) phosphate; (2) nitrate; (3) phosphate and nitrate; (4) phosphate and iron; (5) nitrate and iron; (6) phosphate, nitrate and iron (Table 1).

The sampling was carried out every fourth day directly after the nutrient additions. The water in the bags was mixed by moving a piston-shaped stirring device twice up and down, and a 11 water sample was withdrawn from each bag with a $1.5 \mathrm{~m}$ integrating tube sampler. Back in the laboratory, analyses and preparations were done the same day as the sampling. $\mathrm{pH}$ was measured, and a $100 \mathrm{ml}$ sub-sample was preserved in acid Lugol's solution for the subsequent analysis of the phytoplankton species composition. A 100 to $300 \mathrm{ml}$ sub-sample was filtered through a pre-combusted $4.7 \mathrm{~cm} \mathrm{GF} / \mathrm{F}$ filter, and $20 \mathrm{ml}$ of the filtrate was frozen for later ammonium and nitrate analyses. Half of each filter was used for colorimetric chlorophyll a analysis using ethanol extraction according to Jespersen \& Christoffersen (1987), while the other half was dried for $\mathrm{C}$ and $\mathrm{N}$ analyses (Carbo-Erba analyzer). Nutrients were analyzed according to the following procedures (detection limits within brackets): nitrate, Alpkem autoanalyzer $\left(5 \mu \mathrm{g} \mathrm{l}^{-1}\right)$; ammonium, indolphenol method $(2 \mu \mathrm{g}$ $\left.\mathrm{l}^{-1}\right)$; total nitrogen (tot-N), sum of nitrate, nitrite and Kjeldahl-N (which is digestion of unfiltered water with potassium sulfate and concentrated sulfuric acid, followed by distillation and ammonium determination as above); molybdate reactive phosphorus (filtered water [Murphy \& Riley 1962] $5 \mu \mathrm{g} \mathrm{l}^{-1}$ ); total phosphorus (unfiltered 
water [Menzel \& Corwin 1965] $5 \mu \mathrm{g} \mathrm{l}^{-1}$ ); and reactive reducible iron (RRFe), tripyridyltriazine method (filtered water, Collins \& Diehl 1960, $2 \mu \mathrm{g} \mathrm{l}^{-1}$ ). All the equipment was washed with diluted $\mathrm{HCl}$ before experiments and analyses. The phytoplankton samples from Days 0, 4, 12 and 25 were counted using an inverted phase-contrast microscope as described by Olrik et al. (1998). The phytoplankton volumes were estimated using geometrical formulas and converted to biomass assuming a density of $1 \mathrm{~g} \mathrm{~cm}^{-3}$. This method does not include picoplankton. Time response of different parameters were evaluated with linear regression using the JMP software (SAS Institute). Significance was tested at the $5 \%$ level.

\section{RESULTS}

At the start of the experiment, the concentration of RRFe was on average $20 \mu \mathrm{g} \mathrm{Fe} \mathrm{l}^{-1}$ in all enclosures. This concentration had decreased below the limit for detection on Day 16, while the decrease in RRFe concentration outside the enclosures leveled off at $10 \mu \mathrm{g}$ $\mathrm{l}^{-1}$. In the enclosures receiving iron every fourth day, the concentration remained at about $50 \mu \mathrm{gRFe}^{-1}$ but did not accumulate. Outside the enclosures, the concentrations of phosphate and ammonium were below the levels of detection during the entire experiment. Even though samples from the enclosures were retrieved immediately after the nutrient additions, concentrations of phosphate, nitrate and ammonium also remained below the level of detection in all enclosures during the experiment. Only part of the nitrate additions (ca. $30 \mu \mathrm{g} \mathrm{l}^{-1}$ ) was detected in enclosures receiving nitrate. At the start of the experiment, particulate (part) $\mathrm{N}$ was $0.66 \mathrm{mg} \mathrm{l}^{-1}$ and tot-N $0.9 \mathrm{mg} \mathrm{l}^{-1}$. Total phosphorus concentration was $70 \mu \mathrm{g} \mathrm{l}^{-1}$ at the start of the experiment and remained at about that level in the 4 enclosures supplied with phosphorus, while the other 3 enclosures lost about half of their total phosphorus content over the experimental period.

As indicated by the increase in $\mathrm{pH}$ during the incubation period, there were high rates of primary production in all enclosures during the experiment (Fig. 1A). At the start of the experiment, the average $\mathrm{pH}$ in the enclosures was 8.2. On Day 4, the $\mathrm{pH}$ values were significantly higher in the enclosures to which nitrate had been added than in the other enclosures (Student's $t$-test, $p<0.05$ ). In the 2 enclosures receiving nitrate but not phosphate $(\mathrm{N}-$ and FeN- bags) the $\mathrm{pH}$ leveled off at 9.3, while $\mathrm{pH}$ values as high as 10.0 were recorded at the end of the incubation period in bags receiving both nitrate and phosphate. By the end of the experiment, the $\mathrm{pH}$ values in the 4 bags receiving phosphate were similar regardless of additions of nitrate or iron (Fig. 1A).

In the 4 enclosures receiving phosphate, the chlorophyll a concentration increased significantly (linear regression, $\mathrm{r}^{2}: 0.67$ to 0.86 ; Fig. 1B) during the incubation period. At the end of the experiment, the highest chlorophyll a concentrations were found in the enclosures receiving phosphate but not nitrate (P- and FePbags; Fig. 1B). In the enclosures not receiving phosphate (N-bags, FeN-bags and the unfertilized control bag), no significant increases in chlorophyll a concentrations were detected (Fig. 1B).

In the enclosures not receiving phosphate, no significant increases in concentrations of particulate carbon or part-N were detected (Fig. 2). From Day 8 onwards, particulate carbon and part- $\mathrm{N}$ increased significantly in the 4 bags receiving phosphate (linear regression Day 8 to $25, r^{2}: 0.95$ to 0.99 ). At the end of the experiment, the highest concentrations of particulate carbon and part-N were found in the enclosures receiving phosphate but not nitrate (P- and FeP-bags; Fig. 2). This part-N increase (average of P-bag and FeP-bag) can be related to added phosphorus during the experimental elapse. The part- $\mathrm{N}$ increase as a response to added phosphorus corresponds to a molar ratio of 36:1 (average part- $\mathrm{N}$ increase per added phosphorus in P-bag and FeP-bag).

At the start of the experiment, the phytoplankton biomass was $5 \mathrm{mg}$ wet wt $\mathrm{l}^{-1}$. Half of the biomass consisted of cyanobacteria (Chroococcales, mainly Merismopedia and Snowella; Oscillatoriales Lyngbya; and Nostocales Anabaena and Aphanizomenon), while the

\begin{tabular}{|llll|}
\hline$\triangle \mathrm{FePN}$ & $\circ \mathrm{FeP}$ & $\times \mathrm{FeN}$ & + Control \\
$\triangle \mathrm{NP}$ & $-\mathrm{P}$ & $* \mathrm{~N}$ & - Experimental site \\
\hline
\end{tabular}
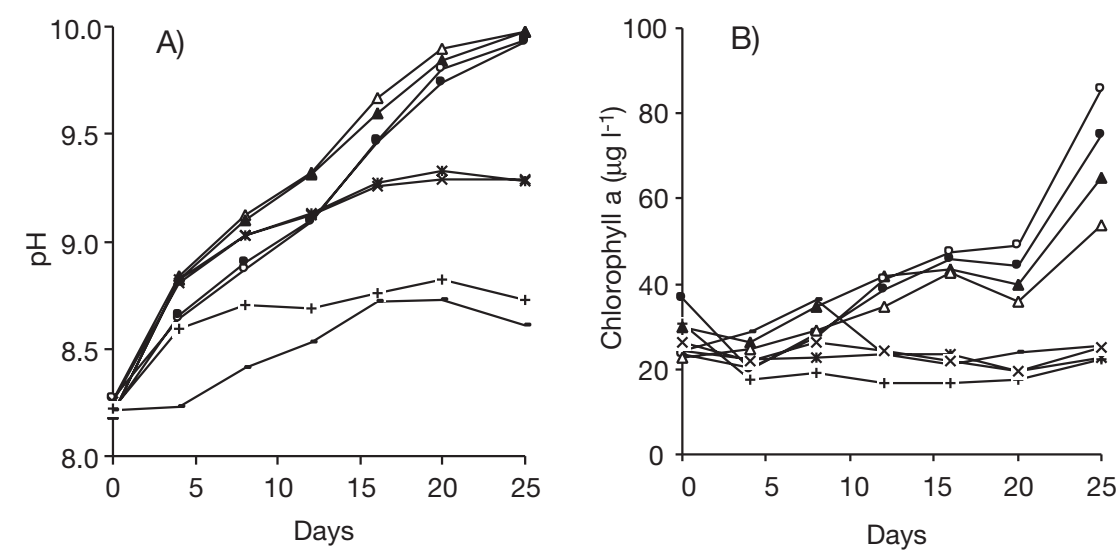

Fig. 1. (A) pH and (B) chlorophyll a development over the experimental period in the 7 enclosures and at the experimental site 


\begin{tabular}{|llll|}
\hline$\triangle \mathrm{FePN}$ & $\circ \mathrm{FeP}$ & $\times \mathrm{FeN}$ & + Control \\
$\triangle \mathrm{NP}$ & $-\mathrm{P}$ & $* \mathrm{~N}$ & - Experimental site \\
\hline
\end{tabular}
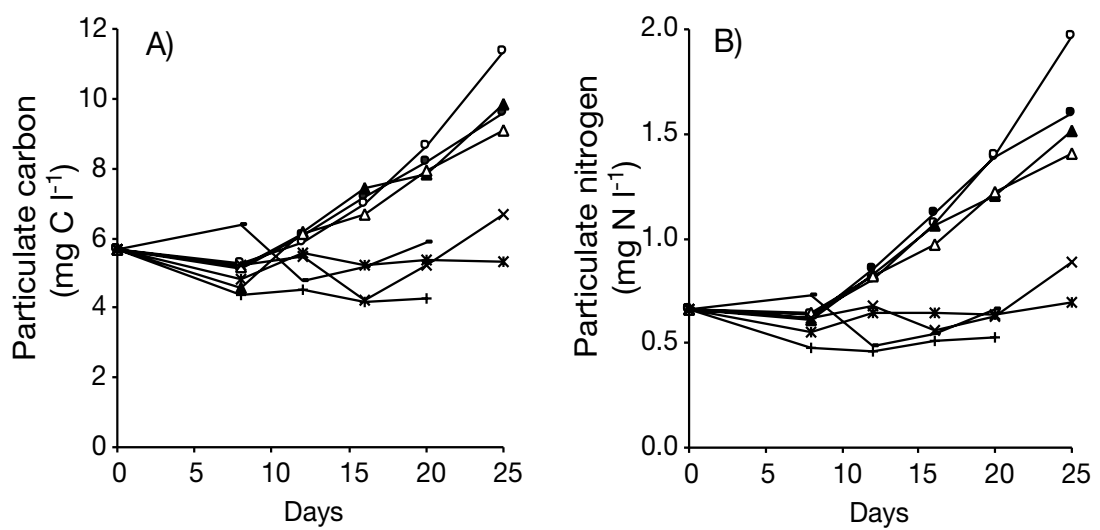

Fig. 2. (A) Particulate carbon and (B) particulate nitrogen development over the experimental period in the 7 enclosures and at the experimental site. Data are missing for Day 25 for the control enclosure and outside the enclosures (experimental site) remaining half consisted of a diverse mixture of chryso- and cryptophyceans, green algae and dinoflagellates. No significant increase in the biomass of eukaryotic phytoplankton occurred in any of the enclosures (Fig. 3). However, in the 4 enclosures receiving phosphate, the phytoplankton biomass increased 2 to 3 times during the experiment. This increase was largely due to significant increases in the biomass of nitrogenfixing cyanobacteria (linear regression, $\mathrm{r}^{2}$ : 0.98 to 0.99; Fig. 3A-D), mainly Anabaena sp. and Aphanizomenon sp. At the end of the experiment, the highest phytoplankton biomasses were recorded in the enclosures receiving phosphate but not nitrate (P- and FeP-bags). In the $\mathrm{P}$ and $\mathrm{FeP}$ enclosures, nitrogen-fixing cyanobacteria constituted 84 and $91 \%$ of
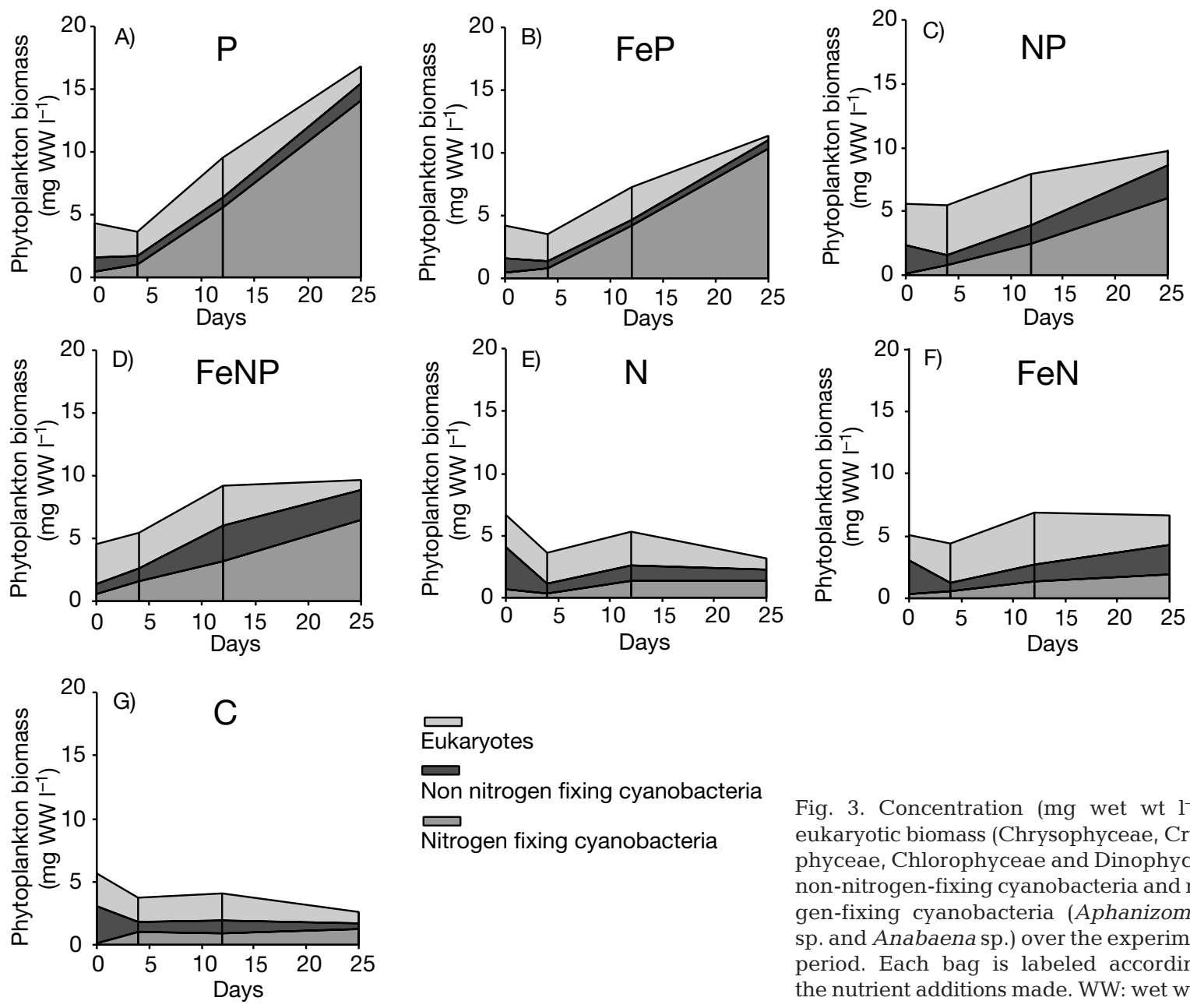

Fig. 3. Concentration (mg wet wt $\mathrm{l}^{-1}$ ) of eukaryotic biomass (Chrysophyceae, Cryptophyceae, Chlorophyceae and Dinophyceae), non-nitrogen-fixing cyanobacteria and nitrogen-fixing cyanobacteria (Aphanizomenon sp. and Anabaena sp.) over the experimental period. Each bag is labeled according to the nutrient additions made. WW: wet weight 
the phytoplankton biomass, respectively. In the enclosures also receiving nitrate (NP and FeNP), nitrogenfixing cyanobacteria constituted 61 to $67 \%$ of the phytoplankton biomass (Fig. 3C,D).

\section{DISCUSSION}

This study shows that summer phytoplankton biomass development was limited by phosphorus and not by nitrogen or iron in this region of the Baltic coast. It also shows that the nitrogen content of the water can increase when phosphorus alone is added, an increase that is most likely caused by the activity of nitrogenfixing cyanobacteria.

The average part- $\mathrm{N}$ increase in the P- and FeP-bags (Fig. 2) was high compared to nitrogen fixation rates of between 0.06 and $1.8 \mathrm{~g} \mathrm{~N} \mathrm{~m}^{-2} \mathrm{yr}^{-1}$ that have been reported for the Baltic (Howarth et al. 1988 and references therein). The amount of nitrogen fixed from Day 8 to the end of the experiment (Day 25) corresponds to $2.3 \mathrm{~g} \mathrm{~N} \mathrm{~m}^{-2}$, or $130 \mathrm{mgN} \mathrm{m}^{-2} \mathrm{~d}^{-1}$. Only a few eutrophic lakes worldwide fix such a high amount of nitrogen per year (Howarth et al. 1988). Off-shore measurements in the Baltic proper found nitrogen fixation rates between 30 and $80 \mathrm{mg}$ nitrogen $\mathrm{m}^{-2} \mathrm{~d}^{-1}$, and the cyanobacterial N:P ratio (molar) increased by a factor of 10 from spring, reaching values around 40:1 during summer (Larsson et al. 2001). This is in agreement with the increase in part- $\mathrm{N}$ per added phosphorus found in this study, indicating an efficient cyanobacterial use of added phosphorus in terms of nitrogen fixing.

It is perhaps not surprising that the nitrogen fixers were triggered by phosphorus, considering the relatively high water temperature and the long duration of the experiment, which allowed the more slowly growing cyanobacteria to develop and dominate the phytoplankton community. The apparent lack of response of potentially nitrogen-limited eukaryotes in the N- and FeN-bags might be explained by zooplankton grazing, since photosynthesis carbon fixation (as indicated by $\mathrm{pH}$ ) rapidly responded to nitrogen additions (Fig. 1A). Another explanation for the initial rapid $\mathrm{pH}$ increase in bags with nitrate additions might be assimilation of nitrate and the subsequent release of $\mathrm{OH}^{-}$. However, in bags receiving both nitrogen and phosphorus, at a molar ratio of 16:1, non-nitrogen-fixing cyanobacteria and eukaryotes increased and seem to have depressed the development of nitrogen-fixing species (Fig. 3). This result suggests that the eukaryotes were co-limited by nitrogen and phosphorus, a reasonable explanation considering that neither phosphate, nitrate nor ammonia was present in measurable amounts at the start of the experiment. A higher ratio of added nitrogen to phosphorus than 16:1 (molar) may have further stimulated growth of eukaryotes and non-nitrogen-fixing cyanobacteria, thereby suppressing the development of nitrogen-fixing cyanobacteria.

The experimental addition of phosphorus is comparable to the potential phosphorus loading through phosphorus release from the sediment, and the addition maintained the initial total phosphorus level. The bags received an equivalent of $5.6 \mathrm{mgP} \mathrm{m}^{-2} \mathrm{~d}^{-1}$ over the experimental period, which is within the range of reported internal phosphorus loading from mesotrophic lake sediments worldwide (2 to $10 \mathrm{mgP} \mathrm{m}^{-2}$ $\mathrm{d}^{-1}$, Nürnberg 1988). Effective nutrient cycling between sediment and water in this unstratified system explains its productive character. High temperature in the surface sediment during summer causes reductions in iron and phosphorus retention due to high microbial activity (Jensen et al. 1995).

The concentration of dissolved iron at the start of the experiment $\left(20 \mu \mathrm{gRRFe} \mathrm{l}^{-1}\right)$ probably met the needs of phytoplankton growth throughout the experiment since no stimulatory effects of the iron additions were measured. Off-shore measurements made 3 decades ago in the Baltic proper never found a total iron concentration above $10 \mu \mathrm{g} \mathrm{l}^{-1}$ in surface water $(0$ to $10 \mathrm{~m}$ depth) samples (Sen Gupta 1972). Iron limitation of cyanobacteria in the Baltic has previously been suggested (Balode et al. 1998, Hellström 1998, Stal et al. 1999), since iron is required in nitrogenase, the enzyme responsible for nitrogen fixing. Wu et al. (2000) suggest that primary production in the ocean is phosphorus-limited when there is a sufficient supply of iron, i.e. not limiting nitrogen fixation. Their results, although based on oligotrophic ocean waters, might also be valid for the Baltic. However, no effect of iron additions was found on the phytoplankton community development in this study.

This preliminary study clearly shows the importance of phosphate additions for stimulating phytoplankton growth mainly by stimulating nitrogen-fixing cyanobacteria, and suggests that the other factors (nitrogen and iron) are less important. Altogether, our results indicate that a reduction of nitrogen loading, without a reduction of phosphorus load, may trigger growth of nitrogen-fixing cyanobacteria, at least in shallow areas along the Baltic coast. However, future studies need to include replicated treatments to confirm our conclusions.

Acknowledgements. Financial support was received from the MISTRA, Lamm and Trygger foundations. We express our gratitude to Dan Höxter for providing equipment at the experimental site, and to Karin Rengefors for linguistic revision. 


\section{LITERATURE CITED}

Balode M, Purina I, Béchemin C, Maestrini SY (1998) Effects of nutrient enrichment on the growth rates and community structure of summer phytoplankton from the Gulf of Riga, Baltic Sea. J Plankton Res 20:2251-2272

Bianchi T, Engelhaupt E, Westman P, Andrén T, Rolff C, Elmgren R (2000) Cyanobacterial blooms in the Baltic sea: natural or human-induced? Limnol Oceanogr 45:716-726

Carman R, Jonsson P (1991) Distribution patterns of different forms of phosphorus in some surficial sediments of the Baltic Sea. Chem Geol 90:91-106

Collins P, Diehl H (1960) Tripyridyltrazine, a reagent for the determination of iron in sea water. J Mar Res 17-18: 152-156

Granelí E, Wallström K, Larsson U, Granelí W, Elmgren R (1990) Nitrogen and phosphorus limitation. Ambio 19: 142-151

Grimvall A, Stålnacke P, Tonderski A (2000) Time scales of nutrient losses from land to sea: a European perspective. Ecol Eng 14:363-371

Hellström T (1998) Why nitrogen is not limiting production in the seas around Sweden. In: Effects of nitrogen in the aquatic environment. The Royal Swedish Academy of Sciences, Stockholm, KVA Report 1:11-22

Howarth RW, Marino R (1998) A mechanistic approach to understanding why so many estuaries and brackish waters are nitrogen limited. In: Effects of nitrogen in the aquatic environment. The Royal Swedish Academy of Sciences, Stockholm, KVA Report 1:117-136

Howarth RW, Marino R, Lane J, Cole JJ (1988) Nitrogen fixation in freshwater, estuarine, and marine ecosystems. 1. Rates and importance. Limnol Oceanogr 33:669-687

Hyenstrand P, Rydin E, Gunnerhed M (1999) Response of pelagic cyanobacteria to iron additions: enclosure experiments from Lake Erken, Sweden. J Plankton Res 22: 1113-1126

Jensen HS, Mortensen PB, Andersen FØ, Rasmussen E, Jensen A (1995) Phosphorus cycling in a coastal marine sediment, Aarhus Bay, Denmark. Limnol Oceanogr 40: 908-917

Jespersen AM, Christoffersen K (1987) Measurements of chlorophyll-a from phytoplankton using ethanol as extraction solvent. Arch Hydrobiol 109:445-454

Editorial responsibility: Otto Kinne (Editor), Oldendorf/Luhe, Germany
Jonsson P, Carman P, Wulff F (1990) Laminated sediments in the Baltic: a tool for evaluating nutrient mass balances. Ambio 19:152-158

Larsson U, Elmgren R, Wulff F (1985) Eutrophication and the Baltic sea: causes and consequences. Ambio 14:9-14

Larsson U, Hajdu S, Walve J, Elmgren R (2001) Baltic Sea nitrogen fixation estimated from the summer increase in upper mixed layer total nitrogen. Limnol Oceanogr 46:811-820

Menzel DH, Corwin N (1965) The measurement of total phosphorus in seawater based on the liberation of organically bound fractions by persulfate oxidation. Limnol Oceanogr 10:280-282

Mortimer CH (1941) The exchange of dissolved substances between mud and water in lakes. 1. J Ecol 29:280-329

Mortimer CH (1942) The exchange of dissolved substances between mud and water in lakes. 2. J Ecol 30:147-201

Murphy J, Riley JP (1962) A modified single-solution method for the determination of phosphate in natural waters. Anal Chim Acta 27:31-36

Niemi Å (1979) Blue-green algal blooms and N:P ratio in the Baltic sea. Acta Bot Fenn 110:57-61

Nürnberg GK (1988) Prediction of phosphorus release rates from total and reductant soluble phosphorus in anoxic lake sediments. Can J Fish Aquat Sci 45:574-580

Olrik K, Blomqvist P, Brettum P, Cronberg G, Eloranta P (1998) Methods for quantitative assessment of phytoplankton in freshwaters. 1. Swedish Environmental Protection Agency Report 4860. Swedish Environmental Protection Agency, Stockholm

Persson J, Jonsson P (2000) Historical development of laminated sediments: an approach to detect soft sediment ecosystem changes in the Baltic Sea. Mar Pollut Bull 40: 122-134

Sen Gupta RS (1972) On some trace metals in the Baltic. Ambio 1:226-230

Stal LJ, Staal M, Villbrandt M (1999) Nutrient control of cyanobacterial blooms in the Baltic Sea. Aquat Microb Ecol 18:165-173

Willén T, Mattsson R (1997) Water-blooming and toxinproducing cyanobacteria in Swedish fresh and brackish waters, 1981-1995. Hydrobiologia 353:181-192

Wu J, Sunda W, Boyle EA, Karl DM (2000) Phosphate depletion in the western North Atlantic Ocean. Science 289: 759-762

Submitted: January 19, 2001; Accepted: March 19, 2002 Proofs received from author(s): August 6, 2002 